\title{
An in silico approach to target SARS-CoV-2 RNA dependent RNA polymerase of COVID-19 with naturally occurring phytochemicals
}

\section{Hafiza Salaha Mahrosh}

Department of Biochemistry, Government College University, Faisalabad-38000, Pakistan

Ghulam Mustafa ( $\nabla$ gmustafa_uaf@yahoo.com)

Department of Biochemistry, Government College University, Faisalabad-38000, Pakistan

https://orcid.org/0000-0001-6510-6496

\section{Research Article}

Keywords: SARS-CoV-2, molecular docking, phytochemicals, RNA dependent RNA polymerase, nsp-12

Posted Date: November 16th, 2020

DOI: https://doi.org/10.21203/rs.3.rs-107572/v2

License: (c) (i) This work is licensed under a Creative Commons Attribution 4.0 International License.

Read Full License 


\title{
An in silico approach to target SARS-CoV-2 RNA dependent RNA polymerase of COVID-19 with naturally occurring phytochemicals
}

\author{
Hafiza Salaha Mahrosh and Ghulam Mustafa* \\ Department of Biochemistry, Government College University, Faisalabad-38000, Pakistan \\ *Corresponding author \\ Email: gmustafa_uaf@yahoo.com
}

\begin{abstract}
The novel coronavirus disease 2019 (COVID-19) was firstly reported from Wuhan city of China found as highly contagious, transmittable and pathogenic viral infection. The World Health Organization declared COVID-19 as a pandemic since its emergence from China. The RNA dependent RNA polymerase (nsp-12) is a complex with nsp-7 and nsp-8 cofactors major constituent of viral replication and RNA synthesis machinery. In current study, the RdRp of virus was selected as a receptor protein for computational drug discovery. Computational homology modelling was done in order to find the hidden secondary structures and structural assessment of viral protein to target them via antiviral drugs. The study based on docking of different phytochemicals to check potential of different plant metabolites against viral replicative proteins. Out of 200 ligands used in this study from different plants the best ten were selected based on drug discovery parameters such as S-score, ligand interactions, hydrophobic interactions and drug likeness. The ten best selected ligands were Verbenalin, Epigallocatechin, Swertisin, Nobiletin, Pinoresinol, Caftaric acid, Hesperetin, Islandicin, Neochlorogenic acid and Sesamin that exploit the potency as antagonist of viral protein. Among binding interactions of all ligands Arg339 centred as the main interacting residue among almost all the ligands. Till now many antiviral agents have shown potency in only mild cases of SARS-CoV-2 but no effective drug has been found for critical pulmonary cases. In clinical trials many broad-spectrum antiviral agents have been still in trail periods of testing against SARS-CoV-2. Till date no effective drug or vaccine has been validated with significant efficacy and potency against the SARS-CoV-2 therefore there is an urgent need to design effective vaccine against nCoV-19 infections.
\end{abstract}

Keywords: SARS-CoV-2; molecular docking; phytochemicals; RNA dependent RNA polymerase; nsp-12

\section{Introduction}


A new human coronavirus (n-CoV), lately in December 2019 emerged from Wuhan city, China that resulted in mysterious coronavirus outbreak globally. World health organization (WHO) declared COVID-19/SARS-CoV-2 as a highly transmissible disease leads from mild to critical pulmonary infections around the globe. The case studies of SARS-CoV-2 infections pointed towards its connection with sea food market but still no evidence has been found to support them. The nCoV-19 infections mainly include pulmonary stress, fever, poor renal functioning, sputum production, anosmia, ageusia and multiple misfunctioning (Ji et al., 2020).

The rapid spread of nCoV-19 infections globally gained the attention and created apprehension worldwide. In the past, the two beta coronavirus outbreaks (i.e. SARS and MERS) were occurred which were less severe and contagious with 35\% fatality rate (Yu et al., 2020). New novel coronavirus has been recognized as a new member of beta genus of Coronaviridae family (Gao et al., 2020). Four major genera of coronaviruses (i.e. alpha, beta, gamma and delta) have been discovered (Saif et al., 2019). Coronaviruses are positive single stranded enveloped 3 kb RNA viruses. All corona viruses possess specific gene in their ORF region that encodes for viral replicative, spike and capsid proteins (Shereen et al., 2020).

Coronaviruses (CoVs) employ two open reading frames ORF1a and ORFlab and the polyproteins further split and code structural and non-structural viral proteins. Structural protein has been characterized as spike $(\mathrm{S})$, membrane $(\mathrm{M})$, nucleocapsid $(\mathrm{N})$ and envelope $(\mathrm{E})$ protein while nonstructural proteins include a range from nsp1 to nsp16 (Khan et al., 2020). Along with nCoV-spike protein the RNA dependent RNA polymerase is the main viral protease directly involved in human cell infections. RNA dependent RNA polymerase (nsp-12) of novel coronavirus exists in complex form associated with two other non-structural proteins i.e. nsp7 and nsp8. Due to this complex formation, the RNA dependent RNA polymerase (nsp-12) of nCoV-19 adopts right hand shape and looks like finger, palm and thumb domains.

RNA dependent RNA polymerase (nsp-12) complexed with two cofactors nsp7 and nsp8 plays a key role in RNA synthesis, transcription and replication process of the SARS-CoV-2. Thus, nsp12 is considered as the main target for different antiviral agents to hinder the replication cycle of nCoV-19 directly (Gao et al., 2020). The RNA dependent RNA polymerase of nCoV-19 is directly involved in transcription and replication process of virus hence looks an excellent target for antiviral agents. Ongoing COVID-19 outbreak related to highly pathogenic form of nCoV-19 strain has highlighted the necessities of urgent need of drug development. The emerging nCoV-19 
infections demand nucleotide analogues based antiviral therapies directly targeted the external components of replication machinery of nCoV-19 RNA virus (Gao et al., 2020). Therefore, the current study was planned to target RNA dependent RNA polymerase by different phytochemicals to inhibit viral transcription and replication.

\section{Materials and Methods}

Swiss Model server was used to build 3D structure of RNA dependent RNA polymerase (nsp12) (GenBank accession number: YP_009725307.1) of SARS-CoV-2. 6M71_A from Protein Data Bank (PDB) was used as a template. The predicted 3D models were evaluated via verify 3D (Lüthy et al., 1992), ERRAT (Colovos and Yeates, 1993) and Swiss Model Ramachandran plot (Waterhouse et al., 2018). The superimposition of predicted 3D model and template was done through UCSF chimera work bench (Pettersen et al., 2004).

\section{Ligand database preparation and receptor refinement}

From the extensive survey, 200 ligands were listed specifically from medicinal plants. Chemical structures of all the ligands were retrieved from PubChem database (http://www.ncbi.nlm.nih.gov/pccompound) in SDF format and after energy minimization saved into MOE database. The predicted 3D model of nsp12 was used as a receptor protein. Optimization of receptor was done by removal water molecules, addition of hydrogens, energy minimization and 3D protonation for the perfect and accurate docking. The minimized structure was then docked against selected ligands.

\section{Molecular docking}

Molecular docking was performed at the active site in chain A of nsp-12 of SARS-CoV-2. Site finder tool was used to find the binding residues and set the selected parameters such as re-scoring 1: London dG, Retain: 10, refinement: force field; re-scoring 1: London dG, retain: 10 to calculate the interactions of ligands with the binding residues of nsp-12 protein of SARS-CoV-2. Then prepared ligands were docked with the RNA dependent RNA polymerase (nsp-12) of SARS-CoV2 using Molecular Operating Environment (MOE). Most appropriate interactions and bindings between the receptor protein of nCoV-19 and ligands were selected on the basis of S-score, root mean squared deviation (RMSD) and energy validation rankings.

\section{Drug Scanning}

Drug likeness was executed following the "Lipinski's rule of five" (http://www.scfbioiitd.res.in/software/drugdesign/lipinski.jsp). Lipinski's rule of five reveals the drug-like or non- 
drug-like molecules and prognosticates high probability of success and failure of drug candidates in preclinical stage complying with five rules. This rule determines the druglikeliness on the basis of molecular mass $(<500)$, Hydrogen donator $(\leq 5)$ and acceptor $(\leq 10)$, Log P value $(\leq 5)$ and molecular refractivity index (between 40-130) (Lipinski, 2004).

\section{ADMET profiling}

Furthermore, ADMET based chemical scanning of drugs was done using the online comprehensive tool admetSAR (Cheng et al., 2012). Evaluation of ADMET properties (Absorption, Distribution, Metabolism, Excretion, and Toxicity) of potential drug molecules has become important part of in silico drug development and discovery. ADMET based drug classification based on substructure recognition pattern of molecules helps to predict the likeness of drug from perspective of medical chemistry.

\section{Results}

SARS-CoV-2 or nCoV-19 has been listed as a new species among beta corona viruses and declared as a causative agent of recently on going pandemic worldwide. RNA dependent RNA polymerase is a key protein of viral genome that mediates the replication and RNA synthesis machinery of nCoV-19. Therefore, the RNA dependent RNA polymerase (nsp-12) was selected in this study to explore the structural assessment and binding sites of viral protein in order to target them. The purpose of this study was to construct a receptor to be targeted by selected ligand molecules from medicinal plants. All 200 ligands from different classes of medicinal plants were docked against the selected receptor protein of SARS-CoV-2 (nsp-12).

\section{Homology modelling}

Protein sequence of nsp-12 of nCoV-19 was used to develop 3D structure via Swiss Model (Waterhouse et al., 2018). Swiss Model is a fully automated protein homology modelling server which provides structural assessments, comparative modelling and prediction of templates to understand the properties and functioning of proteins. The modelled 3D structure of nsp-12 has been shown in Fig. 1a and its superimposition with selected template in Fig. 1b.

The superimposition of predicted model and template 6M71_A exhibited RMSD value of 0.172 and Q-score: 0.954. Predictions of RMSD and Q-mean were done via UCSF Chimera. Low RMSD value indicates the accuracy and validity of the predicted model. Quality and structural assessment of predicted model was verified using different servers such as Verify 3D, ERRAT and Swiss Model Ramachandran Plot. These servers demonstrated the quality of the predicted model 
by checking the refinement, structure and resolution of the model. Verify 3D uses the 3D profile of protein to assess and analyse the compatibility of the model. The evaluation of predicted model of nsp-12 has been given in Fig. 2 .

According to Verify 3D, $89.20 \%$ of amino acids of nsp-12 exhibited an average 3D-1D score of $\geq 0.2$ which indicated the accuracy and validity of the model (Fig. 2a). The ERRAT predicted the overall Quality Factor that showed that $95 \%$ of amino acid residues fall below the threshold level that centered the fitness of the predicted model (Fig. 2b). Swiss Model Ramachandran plot is dedicated to the stereo-chemical validation and reliability of the predicted model. Ramachandran plot analyzes the main torsion angles Phi, Psi $(\varphi, \psi)$ of amino acid residues in a polypeptide chain present in the protein. According to Ramachandran plot, about $96.05 \%$ residues fall in the favored regions, $0.56 \%$ in Ramachandran outliers with 1.03 MolProbity score confirmed the accuracy of the predicted model (Fig. 2c).

\section{Molecular Docking}

A ready-to-dock library of 200 selected phytochemicals was prepared and then docked with nsp12 receptor protein using docking algorithm of MOE software. MOE confirms correct conformation of ligand for getting a minimum energy structure. Top ten conformations of phytochemicals were determined through docking which occupied maximum binding pocket, strong hydrogen bonding and with best S-score and RMSD value. MOE provided multiple conformations of each phytochemical and on the basis of minimum S-score, the top 10 selected phytochemicals were: Verbenalin, Epigallocatechin, Swertisin, Nobiletin, Pinoresinol, Caftaric acid, Hesperetin, Islandicin, Neochlorogenic acid and Sesamin. Details of each ligand with their S-scores, RMSD values and interacting residues are given in Table 1.

\section{Interaction Analysis}

Among 200 selected ligands, top 10 were selected on the basis of minimum S-Score and binding interactions with SARS-CoV-2 receptor molecule. First phytochemical, verbenalin formed five interactions with different residues of receptor molecule (i.e. Arg349, Ser664, Asn628, Pro677 and Glu350). Verbenalin is terpene glycoside extracted from Verbena officinalis that is a medical herb and used for various clinical purposes such as influenza, malaria, headaches, fever and dermatitis treatment.

The second phytochemical, Epigallocatechin has showed interactions with Ser664, Phe326 and Glu665 residues of the receptor protein. Being an antioxidant in nature it provides protection 
against free radicals in the body. Epigallocatechin is a major constituent of green tea, black tea and almonds, and plays a role as an antioxidant. Basically it is flavan-3,3',4',5,5',7-hexol and potent catechin and exhibits 2R, 3R-configurations. Third ligand was found to be Swertisin that has been derived from Apigenin and is abundantly found in chamomile plants. Swertisin showed binding interactions with Arg349, Ser664, Phe326, Asn628 and Thr324 amino acid residues respectively. Swertisin plays various roles such as an anti-inflammatory agent, an antioxidant and adenosine A1 receptor antagonist. Fouth ligand was nobiletin that interacted with Arg349 and Tyr346 residues of nsp-12 receptor protein. Nobiletin is a methoxy flavone, an antineoplastic agent with methoxy groups at 5, 6, 7, 8, 3' and 4' positions. Citrus fruits specifically the peel of Citrus nobilis and Citrus aurantium are natural sources of this flavanone.

The fifth phytochemical, pinoresinol exhibited two binding interactions with the receptor (i.e. Ser664 and Tyr346). Pinoresinol is a lignin and enantiomer of (+)-1S, 4S, 3aR Pinoresinol that has been extracted from Forsythia suspensa and Styrax platanifolius. Pinoresinol is a phytoestrogen and hypoglycemic agent. The sixth phytochemical, caftaric acid is the principle esterified phenolic acid and found in grapes, raisins and berries. Caftaric acid showed interactions with Arg349, Lys676 and Leu460 residues of nsp-12. Hesperetin was the seventh phytochemical that formed two interactions with the receptor protein (i.e. Arg349 and Glu350) Hesperetin with three hydroxy groups is a trihydroxy flavanone and have anti-inflammatory, antioxidant, anti-allergic, vasoprotective and hypolipidemic properties. Citrus fruits are the natural source of hesperetin and therefore also used in lowering the cholesterol level.

The eighth phytochemical, islandicin exhibited two binding interactions with Arg349 and Tyr346 residues of the nsp-12. Islandicin is a trihydroxyanthraquinone and belongs to organic compound class anthraquinones. It has been extracted from the roots and bark of Ventilago madraspatana plant. Neochlorogenic acid or trans-5-caffeoylquinic acid was the ninth phytochemical which is a cinnamate ester. Neochlorogenic acid formed interactions with Arg349, Tyr346 and Phe396 residues of the nsp-12. The compound is produced during the metabolic pathways in plants. Neochlorogenic acid is abundantly found in Prunus persica (peaches) but also present in Vaccinium corymbosum (Highbush blueberry), Levisticum officinale (Lovage) and Arctium (Burdock root). The tenth phytochemical, sesamin is a lignin and has been extracted from Cinnamomum camphora (Camphor tree). Sesamin showed interactions with two amino acid residues of the receptor protein (i.e. Ser664, Thr462). It exhibits various properties such as 
neuroprotective and antineoplastic agent, and also exerts cytotoxic effects. Results demonstrated the potential of these ligands as they can block the target site (i.e. viral protein). Therefore, these 10 molecules could be used as potential drugs against COVID-19 in future with no side effects.

\section{Drug Scan}

The Lipinski's rule illustrates five parameters to distinguish the drug-like and non-drug like molecules. According to these parameters molecular mass of the potential drug candidate should be less than 500 Dalton, the molecule should have high lipophilicity ( $\log p \leq 5$ ), hydrogen bond donors should be $\leq 5$, hydrogen bond acceptors should be $(\leq 10)$ and molar refractivity should be significant for drug pharmokinetics in human body (i.e. between 40-130). Only the drug that accomplished all these parameters could be proved as a good drug candidate. All the ligands selected in this study followed the Lipinski's rule and are revealed as potential drug-like molecules with fewer adverse effects (Table 2).

\section{ADMET profiling}

After drug scan, ADMET based properties of drugs molecules were checked. The selected top 10 candidate overall fulfilled the criteria of being good drug candidates as the results illustrated that all compounds are non-toxic except islandicin and swertisin, but all were found to be noncarcinogens. Verbenalin, epigallocatechin, swertisin and hesperetin showed little violations but overall results could be accepted and these lead compounds are appropriate to be used as drug candidates against receptor molecule (Table 3).

\section{Discussion}

Computational biology skills help scientist to evaluate the possibilities of binding mode of different ligands before the experimental work in laboratory. Molecular docking is an elaborative method to discover the interactions of different macromolecules as drugs against the receptor moiety. Molecular docking is an economic and modern drug discovery method that provides valuable information about the active site targeting of particular macromolecule (Qamar et al., 2017). In current study, computational docking of phytochemicals was performed to explore the RdRp antagonists. Among 200 ligands used in this study, top ten phytochemicals with best docking scores were found to be verbenalin, epigallocatechin, swertisin, nobiletin, pinoresinol, caftaric acid, hesperetin, islandicin, neochlorogenic acid and sesamin. Arg349 was found to be the common amino acid residue through binding modes and interaction patterns of docking studies of 
these 10 ligands with nsp-12 of nCoV-19. All the ligands fully accomplished the Lipinski's rule of five and showed no desecration.

The natural flora has been used as medical purposes in various cultures and human inhabitant for decades. A vast variety of phytochemicals with biologically active constituents has been reported from medical plants that have been used for maintaining good health and to the cure many diseases (Mustafa et al., 2016). The extracts from medical plants are comprised of vitamins, minerals and organic acids with fewer side effects (Mustafa et al., 2017). Within span of few months the nCov-19 has caused the worst pandemic COVID-19 or Severe Acute Respiratory Syndrome (SARS-CoV-2) which is an extremely pathogenic and has transmitted with high exponential rate (Gao et al., 2020). Currently, no drugs or clinically approved therapeutics are reported for the treatment of SARS-CoV-2 infections. The urgent necessity at this time is to discover some novel drug candidate(s) to overcome the viral infection caused by nCoV-19 (Adem et al., 2020).

Novel coronavirus belongs to Coronaviridae family and causes acute lung disease accompanied by pulmonary stress and failure, and eventually leads to death. The genome of novel corona virus codes four major structural proteins and 16 non-structural proteins (Khan et al., 2020). In this study, one of the non-structural proteins (i.e. nsp-12 that is an RNA dependent RNA polymerase) was selected. The mystery of viral eradication still needs more studies to explore the full mechanism and machinery of viral genome in order to target it directly. RNA dependent RNA polymerase plays a vital role in the replication, transcriptions and RNA processing machinery of the virus. The RdRp (nsp-12) of SARS-CoV-2 accompanied two more proteins i.e. nsp-7 and nsp8 as cofactors to make RdRp complex with three domains (Kirchdoerfer et al., 2019). Virus upon interaction with its host cells invades into the cell and multiplies by relying on the RNA synthesis machinery. RdRp encodes RdRp proteins that possess crucial ability to mediate replication and synthesis of RNA viruses. Thus, RdRp of nCoV-19 has potential to be targeted by drugs and nucleotide analogues (Chakrabortya et al., 2020).

The aim of this study was to explore three-dimensional structure of nsp-12 through homology modeling and computational docking to check the binding/inhibiting potential of various plantbased ligands against viral protein. Total 200 ligands from different medicinal plants were docked against RNA dependent RNA polymerase (nsp-12) of SARS-CoV-2 to explore their antiviral activities (Gao et al., 2020). 
Antiviral effects of various medicinal plant extract have been the subject matter in various cases and studies. These phytochemicals exert several effects by blocking the viral receptors, interrupting the enzymatic functioning and inhibiting the biosynthetic machinery of the virus. Moreover, many antiviral agents have been reported with maximum antiviral activity (Adem et al., 2020). Verbenalin (a terpene) is a potent inhibitor of transcriptional factors. It has been used for traditional treatments of inflammation, fever and infections (Akbar, 2020). Epigallocatechin is a flavan and an antioxidant abundant phytochemical in the green tea. Epigallocatechin prevents liver cell injury, reduces the oxidative stress and mitigates the induction of pro-inflammatory cells (Baliga et al., 2019). Swertisin is a C- glycoside flavone and used as an antagonist of adenosine A1 receptor, antioxidant, anti-inflammatory agent and hypoglycemic agent (Srivastava et al., 2018).

Nobiletin $\left(5,6,7,8,3^{\prime}, 4^{\prime}\right.$-hexamethoxyflavone) is a flavonoid found in citrus fruits with multifunctional pharmaceutical properties. Nobiletin was reported with various beneficial effects such as antioxidant, anticancer, anti-inflammation, immunomodulator and anti-osteoclast genesis agent (Huang et al., 2016). Pinoresinol is a lignin that is a plant secondary metabolite extensively used as anticancer and antiviral agent (Schroeder et al., 2006). Caftaric acid and its enantiomers have been reported previously with anti-allergic, anti-inflammatory and immunostimulant agents (Bardal et al., 2011). Hesperetin also known as trihydroxy flavanone or citrus flavanone is found in lime, lemon and citrus fruits. The content of hesperetin is highly rich in the peels of citrus fruits. Hesperetin exhibits antiviral, antioxidant, antineoplastic activity and also used for the lowering of blood cholesterol level (Yumol and Ward, 2018). Islandicin is a trihydroxyanthraquinone recorded with enzymatic inhibitory property (Wiart, 2013). Neochlorogenic acid is the most common polyphenolic compound commonly found in dry fruits. It is mainly reported as antioxidant and scavenge for reactive oxidative species in low density lipoproteins (Via and Mechanick, 2019). Sesamin is a lignan and has been isolated from Fagara plants and Cinnamomum camphor and it exhibits antitumor, antioxidant and cytotoxic activities (Sato and Matsui, 2012). No single drug has been found effective against SARS-CoV-2 till date. The RdRp being important viral replication protein could be a suitable target for antiviral agents. Based on the current findings and binding scores, these ligands could be potential inhibitors of nCoV-19 or SARS-CoV-2.

\section{Conclusion}


The current COVID-19 pandemic currently influenced the world severely. This work seeks to find out potential antagonists against SARS-CoV-2. In the current study, plant derived phytochemicals which have been proved effective against many viral and bacterial proteins in literature were used. Out of 200 phytochemicals that were screened, ten were selected based on the hydrophobic interactions, binding amino acid residues and S-scores. Verbenalin, epigallocatechin, swertisin, nobiletin, pinoresinol, caftaric acid, hesperetin, islandicin, neochlorogenic acid and sesamin were found to be the best ones. All ten best selected ligands exhibited strong binding interactions with receptor molecule and $\operatorname{Arg} 349$ was centered in the common side chain as a directly interacting residue. In the light of current results, it can be assumed that these natural phytochemicals could be good antagonists to the viral protein to stop its proliferation. The likeness of these drugs as good antagonists against receptor viral protein has satisfied that these ligands could lead as potential drug candidates against SARS-CoV-2.

\section{Compliance with ethical standards}

\section{Conflict of interest}

The authors declare that they have no conflict of interest.

\section{Ethical approval}

This article does not contain any studies with human participants or animals performed by any of the authors.

\section{References}

Adem, S., Eyupoglu, V., Sarfraz, I., Rasul, A., \& Ali, M. (2020). Identification of potent COVID19 main protease (Mpro) inhibitors from natural polyphenols: An in-silico strategy unveils a hope against CORONA.

Akbar, S. (2020). Handbook of 200 Medicinal Plants: A Comprehensive Review of Their Traditional Medical Uses and Scientific Justifications. Springer Nature, 1887-1893.

Baliga, M. S., Shivashankara, A. R., Venkatesh, S., Bhat, H. P., Palatty, P. L., Bhandari, G., \& Rao, S. (2019). Phytochemicals in the Prevention of Ethanol-Induced Hepatotoxicity: A Revisit. In Dietary Interventions in Liver Disease, 79-89.

Bardal, S. K., Waechter, J. E., \& Martin, D. S. (2011). Applied pharmacology. Elsevier Health Sciences.

Chakrabortya, H. J., Paria, P., Gangopadhyay, A., \& Ganguli, S. (2020). Drug Repurposing against SARS-CoV-2 RDRP-a computational quest against CoVID-19. 
Cheng, F., Li, W., Zhou, Y., Shen, J., Wu, Z., Liu, G., Lee, P. W., \& Tang, Y. (2012). admetSAR: a comprehensive source and free tool for assessment of chemical ADMET properties. 3099-3105.

Colovos, C., \& Yeates, T. O. (1993). Verification of protein structures: patterns of nonbonded atomic interactions. Protein science, 2(9), 1511-1519.

Gao Y, Yan L, Huang Y, Liu F, Zhao Y, Cao L, Wang T, Sun Q, Ming Z, Zhang L., \& Ge J. (2020). Structure of the RNA-dependent RNA polymerase from COVID-19 virus. Science, 368(6492), 779-782.

Huang, H., Li, L., Shi, W., Liu, H., Yang, J., Yuan, X., \& Wu, L. (2016). The multifunctional effects of nobiletin and its metabolites in vivo and in vitro. Evidence-Based Complementary and Alternative Medicine, 14.

Ji, W., Wang, W., Zhao, X., Zai, J., \& Li, X. (2020). Cross-species transmission of the newly identified coronavirus 2019-nCoV. Journal of medical virology, 92(4), 433-440.

Khan, M. F., Khan, M. A., Khan, Z. A., Ahamad, T., \& Ansari, W. A. (2020). Identification of Dietary Molecules as Therapeutic Agents to Combat COVID-19 Using Molecular Docking Studies.

Kirchdoerfer, R. N., \& Ward, A. B. (2019). Structure of the SARS-CoV nsp12 polymerase bound to nsp7 and nsp8 co-factors. Nature communications, 10(1), 1-9.

Lipinski, C. A. (2004). Lead-and drug-like compounds: the rule-of-five revolution. Drug Discovery Today: Technologies, 1(4), 337-341.

Lüthy, R., Bowie, J. U., \& Eisenberg, D. (1992). Assessment of protein models with threedimensional profiles. Nature, 356(6364), 83-85.

Mustafa, G. H. U. L. A. M., Ahmed, S., Ahmed, N. I. S. A. R., \& Jamil, A. M. E. R. (2016). Phytochemical and antibacterial activity of some unexplored medicinal plants of Cholistan desert. Pak. J. Bot, 48(5), 2057-2062.

Mustafa, G., Arif, R., Atta, A., Sharif, S., \& Jamil, A. (2017). Bioactive compounds from medicinal plants and their importance in drug discovery in Pakistan. Matrix Science Pharma, 1(1),17-26.

Pettersen, E. F., Goddard, T. D., Huang, C. C., Couch, G. S., Greenblatt, D. M., Meng, E. C., \& Ferrin, T. E. (2004). UCSF Chimera - a visualization system for exploratory research and analysis. Journal of computational chemistry, 25(13), 1605-1612.

Qamar, M. T., Ashfaq, U. A., Tusleem, K., Mumtaz, A., Tariq, Q., Goheer, A., \& Ahmed, B. (2017). In-silico identification and evaluation of plant flavonoids as dengue NS2B/NS3 protease inhibitors using molecular docking and simulation approach. Pak. J. Pharm. Sci, 30(6), 2119-2137. 
Saif, L. J., Wang, Q., Vlasova, A. N., Jung, K., \& Xiao, S. (2019). Diseases of swine, 488-523.

Sato, F., \& Matsui, K. (2012). Engineering the biosynthesis of low molecular weight metabolites for quality traits (essential nutrients, health-promoting phytochemicals, volatiles, and aroma compounds). In Plant Biotechnology and Agriculture, 443-461

Schroeder, F. C., del Campo, M. L., Grant, J. B., Weibel, D. B., Smedley, S. R., Bolton, K. L., Meinwald, J., \& Eisner, T. (2006). Pinoresinol: a lignol of plant origin serving for defense in a caterpillar. Proceedings of the National Academy of Sciences, 103(42), 15497-15501.

Shereen, M. A., Khan, S., Kazmi, A., Bashir, N., \& Siddique, R. (2020). COVID-19 infection: Origin, transmission, and characteristics of human coronaviruses. Journal of Advanced Research,24,91-98.

Srivastava, A., Dadheech, N., Vakani, M., \& Gupta, S. (2018). Swertisin ameliorates diabetes by triggering pancreatic progenitors for islet neogenesis in Streptozotocin treated BALB/c mice. Biomedicine \& Pharmacotherapy, 100, 221-225.

Via, M. A., \& Mechanick, J. I. (2019). Mechanisms of Nontraditional and Lifestyle Interventions for Bone Health.

Waterhouse, A., Bertoni, M., Bienert, S., Studer, G., Tauriello, G., Gumienny, R., Heer, F. T., de Beer, T. A., Rempfer, C., Bordoli, L., \& Lepore, R. (2018). SWISS-MODEL: homology modelling of protein structures and complexes. Nucleic acids research, 46(W1), W296W303.

Wiart, C. (2013). Lead compounds from medicinal plants for the treatment of neurodegenerative diseases.

Yu, R., Chen, L., Lan, R., Shen, R., \& Li, P. (2020). Computational screening of antagonist against the SARS-CoV-2 (COVID-19) coronavirus by molecular docking. International Journal of Antimicrobial Agents, 106012.

Yumol, J. L., \& Ward, W. E. (2018). The Polyphenolic Compound Hesperidin and Bone Protection. In Polyphenols: Mechanisms of Action in Human Health and Disease, 431-440. 
Table 1. Interaction details of top ten bioactive phytochemicals in the proposed site of nsp-12 of SARS-CoV-2

\begin{tabular}{|c|c|c|c|c|c|}
\hline $\begin{array}{l}\text { Sr. } \\
\text { No. }\end{array}$ & Ligand & $\begin{array}{l}\text { PubChem } \\
\text { ID }\end{array}$ & $\begin{array}{l}\text { S- } \\
\text { Score }\end{array}$ & Interactions & Plant source \\
\hline 1 & Verbenalin & 73467 & 18.2657 & $\begin{array}{l}\text { Arg349, Ser664, Asn628, } \\
\text { Pro677, Glu350 }\end{array}$ & Verbena officinalis \\
\hline 2 & Epigallocatechin & 72277 & $\begin{array}{l}- \\
17.3994\end{array}$ & Ser664, Phe326, Glu665 & $\begin{array}{l}\text { Green tea, Black Tea, } \\
\text { Almonds }\end{array}$ \\
\hline 3 & Swertisin & 124034 & $\begin{array}{l}- \\
17.3726\end{array}$ & $\begin{array}{l}\text { Arg349, Ser664, Phe326, } \\
\text { Asn628, Thr324 }\end{array}$ & Chamomile plants \\
\hline 4 & Nobiletin & 72344 & $\begin{array}{l}- \\
16.8622\end{array}$ & Arg349, Tyr346 & $\begin{array}{l}\text { Citrus fruits (Citrus } \\
\text { nobilis, Citrus aurantium) }\end{array}$ \\
\hline 5 & Pinoresinol & 73399 & $\begin{array}{l}- \\
16.5379\end{array}$ & Ser664, Tyr346 & $\begin{array}{l}\text { Forsythia suspensa, } \\
\text { Styrax platanifolius }\end{array}$ \\
\hline 6 & Caftaric acid & 6440397 & $\begin{array}{l}- \\
16.0059\end{array}$ & Arg349, Lys676, Leu460 & Grapes, Raisins \\
\hline 7 & Hesperetin & 72281 & $\begin{array}{l}- \\
15.8446\end{array}$ & Arg349, Glu350 & Citrus fruits \\
\hline 8 & Islandicin & 10151 & $\begin{array}{l}- \\
15.8130\end{array}$ & Arg349, Tyr346 & Ventilago madraspatana \\
\hline 9 & $\begin{array}{l}\text { Neochlorogenic } \\
\text { acid }\end{array}$ & 5280633 & $\begin{array}{l}- \\
15.8074\end{array}$ & Arg349, Tyr346, Phe396 & $\begin{array}{l}\text { Prunus persica (peaches), } \\
\text { Vaccinium corymbosum } \\
\text { (Highbush blueberry), } \\
\text { Levisticum officinale } \\
\text { (Lovage), Arctium } \\
\text { (Burdock root) }\end{array}$ \\
\hline 10 & Sesamin & 72307 & $\begin{array}{l}- \\
15.8064\end{array}$ & Ser664, Thr462 & $\begin{array}{l}\text { Cinnamomum camphora } \\
\text { (camphor tree), Fagara } \\
\text { plants }\end{array}$ \\
\hline
\end{tabular}


Table 2. Evaluation of selected phytochemicals through Lipinski's rule of five

\begin{tabular}{|c|c|c|c|c|c|c|}
\hline $\begin{array}{l}\text { Sr. } \\
\text { No. }\end{array}$ & Ligand & $\begin{array}{l}\text { Mass }(<500 \\
\text { Dalton) }\end{array}$ & $\begin{array}{l}\text { Hydrogen } \\
\text { Bond Donor } \\
(\leq 5)\end{array}$ & $\begin{array}{l}\text { Hydrogen } \\
\text { Bond } \\
\text { Acceptors } \\
(\leq 10)\end{array}$ & $\begin{array}{l}\log P \\
(<5)\end{array}$ & $\begin{array}{l}\text { Molar } \\
\text { Refractivity } \\
\text { (between 40- } \\
\text { 130) }\end{array}$ \\
\hline 1 & Verbenalin & $388.4 \mathrm{~g} / \mathrm{mol}$ & 4 & 10 & 2.281440 & 88.407188 \\
\hline 2 & Epigallocatechin & $306.27 \mathrm{~g} / \mathrm{mol}$ & 5 & 7 & 0.793260 & 69.010292 \\
\hline 3 & Swertisin & $446.4 \mathrm{~g} / \mathrm{mol}$ & 5 & 10 & 2.156400 & 101.648476 \\
\hline 4 & Nobiletin & $402.4 \mathrm{~g} / \mathrm{mol}$ & 0 & 8 & 3.353699 & 96.957993 \\
\hline 5 & Pinoresinol & $358.4 \mathrm{~g} / \mathrm{mol}$ & 2 & 6 & 3.169009 & 92.616585 \\
\hline 6 & Caftaric acid & $312.23 \mathrm{~g} / \mathrm{mol}$ & 5 & 9 & 0.537570 & 62.092991 \\
\hline 7 & Hesperetin & $302.28 \mathrm{~g} / \mathrm{mol}$ & 3 & 6 & 1.574360 & 70.328896 \\
\hline 8 & Islandicin & $270.24 \mathrm{~g} / \mathrm{mol}$ & 3 & 5 & 1.329360 & 62.673393 \\
\hline 9 & $\begin{array}{l}\text { Neochlorogenic } \\
\text { acid }\end{array}$ & $354.31 \mathrm{~g} / \mathrm{mol}$ & 5 & 9 & 1.285940 & 78.631287 \\
\hline 10 & Sesamin & $354.4 \mathrm{~g} / \mathrm{mol}$ & 0 & 6 & 3.077019 & 87.342995 \\
\hline
\end{tabular}


Table 3. ADMET profile for top ten selected phytochemicals

\begin{tabular}{|c|c|c|c|c|c|c|c|c|c|c|}
\hline Models & Verbenalin & Epigallocatechin & Swertisin & Nobiletin & Pinoresinol & Caftaric acid & Hesperetin & Islandicin & $\begin{array}{l}\text { Neochlorogenic } \\
\text { acid }\end{array}$ & Sesamin \\
\hline \multicolumn{11}{|c|}{ Absorption } \\
\hline Blood-Brain Barrier & BBB- & BBB- & BBB- & $\mathrm{BBB}+$ & $\mathrm{BBB}+$ & $\mathrm{BBB}+$ & BBB- & $\mathrm{BBB}+$ & $\mathrm{BBB}+$ & $\mathrm{BBB}+$ \\
\hline $\begin{array}{l}\text { Human Intestinal } \\
\text { Absorption }\end{array}$ & HIA+ & HIA+ & HIA+ & HIA+ & HIA+ & HIA+ & HIA+ & HIA+ & HIA+ & HIA+ \\
\hline Caco-2 Permeability & Caco2- & Caco2- & Caco2- & Caco2+ & Caco2+ & Caco2- & Caco2+ & Caco2+ & Caco2- & Caco2+ \\
\hline $\begin{array}{l}\text { P-glycoprotein } \\
\text { Substrate }\end{array}$ & Substrate & Substrate & Substrate & Substrate & Substrate & $\begin{array}{c}\text { Non- } \\
\text { Substrate }\end{array}$ & Substrate & Substrate & Substrate & $\begin{array}{c}\text { Non- } \\
\text { Substrate }\end{array}$ \\
\hline $\begin{array}{l}\text { P- } \\
\text { glycoprotein } \\
\text { Inhibitor }\end{array}$ & Inhibitor & Non-inhibitor & $\begin{array}{c}\text { Non- } \\
\text { inhibitor }\end{array}$ & Inhibitor & $\begin{array}{l}\text { Non- } \\
\text { inhibitor }\end{array}$ & $\begin{array}{l}\text { Non- } \\
\text { inhibitor }\end{array}$ & $\begin{array}{c}\text { Non- } \\
\text { inhibitor }\end{array}$ & $\begin{array}{c}\text { Non- } \\
\text { inhibitor }\end{array}$ & $\begin{array}{r}\text { Non- } \\
\text { inhibitor }\end{array}$ & $\begin{array}{l}\text { Non- } \\
\text { inhibitor }\end{array}$ \\
\hline $\begin{array}{l}\text { Renal Organic } \\
\text { Cation Transporter }\end{array}$ & $\begin{array}{c}\text { Non- } \\
\text { inhibitor }\end{array}$ & Non-inhibitor & $\begin{array}{c}\text { Non- } \\
\text { inhibitor }\end{array}$ & Non-inhibitor & $\begin{array}{l}\text { Non- } \\
\text { inhibitor }\end{array}$ & $\begin{array}{c}\text { Non- } \\
\text { inhibitor }\end{array}$ & $\begin{array}{c}\text { Non- } \\
\text { inhibitor }\end{array}$ & $\begin{array}{c}\text { Non- } \\
\text { inhibitor }\end{array}$ & Non-inhibitor & $\begin{array}{c}\text { Non- } \\
\text { inhibitor }\end{array}$ \\
\hline \multicolumn{11}{|c|}{ Metabolism } \\
\hline $\begin{array}{l}\text { CYP450 2C9 } \\
\text { Substrate }\end{array}$ & $\begin{array}{c}\text { Non- } \\
\text { substrate }\end{array}$ & Non-substrate & $\begin{array}{c}\text { Non- } \\
\text { substrate }\end{array}$ & Non-substrate & $\begin{array}{c}\text { Non- } \\
\text { substrate }\end{array}$ & $\begin{array}{c}\text { Non- } \\
\text { substrate }\end{array}$ & $\begin{array}{c}\text { Non- } \\
\text { substrate }\end{array}$ & $\begin{array}{c}\text { Non- } \\
\text { substrate }\end{array}$ & Non-substrate & $\begin{array}{c}\text { Non- } \\
\text { substrate }\end{array}$ \\
\hline $\begin{array}{l}\text { CYP450 2D6 } \\
\text { Substrate }\end{array}$ & $\begin{array}{c}\text { Non- } \\
\text { substrate }\end{array}$ & Non-substrate & $\begin{array}{c}\text { Non- } \\
\text { substrate }\end{array}$ & Non-substrate & $\begin{array}{c}\text { Non- } \\
\text { substrate }\end{array}$ & $\begin{array}{c}\text { Non- } \\
\text { substrate }\end{array}$ & $\begin{array}{c}\text { Non- } \\
\text { substrate }\end{array}$ & $\begin{array}{c}\text { Non- } \\
\text { substrate }\end{array}$ & $\begin{array}{c}\text { Non- } \\
\text { substrate }\end{array}$ & $\begin{array}{c}\text { Non- } \\
\text { substrate }\end{array}$ \\
\hline $\begin{array}{l}\text { CYP450 3A4 } \\
\text { Substrate }\end{array}$ & Substrate & Non-substrate & $\begin{array}{c}\text { Non- } \\
\text { substrate }\end{array}$ & Substrate & $\begin{array}{c}\text { Non- } \\
\text { substrate }\end{array}$ & $\begin{array}{c}\text { Non- } \\
\text { substrate }\end{array}$ & $\begin{array}{c}\text { Non- } \\
\text { substrate }\end{array}$ & $\begin{array}{c}\text { Non- } \\
\text { substrate }\end{array}$ & Non-substrate & $\begin{array}{c}\text { Non- } \\
\text { substrate }\end{array}$ \\
\hline $\begin{array}{l}\text { CYP450 1A2 } \\
\text { Inhibitor }\end{array}$ & $\begin{array}{c}\text { Non- } \\
\text { inhibitor }\end{array}$ & Non-inhibitor & $\begin{array}{c}\text { Non- } \\
\text { inhibitor }\end{array}$ & Inhibitor & $\begin{array}{l}\text { Inhibit } \\
\text { or }\end{array}$ & $\begin{array}{c}\text { Non- } \\
\text { inhibitor }\end{array}$ & $\begin{array}{l}\text { Inhibit } \\
\text { or }\end{array}$ & $\begin{array}{l}\text { Inhibit } \\
\text { or }\end{array}$ & $\begin{array}{c}\text { Non- } \\
\text { inhibitor }\end{array}$ & $\begin{array}{l}\text { Inhibi } \\
\text { tor }\end{array}$ \\
\hline $\begin{array}{l}\text { CYP450 2C9 } \\
\text { Inhibitor }\end{array}$ & $\begin{array}{c}\text { Non- } \\
\text { inhibitor }\end{array}$ & Non-inhibitor & $\begin{array}{c}\text { Non- } \\
\text { inhibitor }\end{array}$ & Non-inhibitor & Inhibitor & $\begin{array}{c}\text { Non- } \\
\text { inhibitor }\end{array}$ & Inhibitor & Inhibitor & Non-inhibitor & Inhibitor \\
\hline $\begin{array}{l}\text { CYP450 2D6 } \\
\text { Inhibitor }\end{array}$ & $\begin{array}{c}\text { Non- } \\
\text { inhibitor }\end{array}$ & Non-inhibitor & $\begin{array}{c}\text { Non- } \\
\text { inhibitor }\end{array}$ & Non-inhibitor & $\begin{array}{c}\text { Non- } \\
\text { inhibitor }\end{array}$ & $\begin{array}{c}\text { Non- } \\
\text { inhibitor }\end{array}$ & Inhibitor & $\begin{array}{c}\text { Non- } \\
\text { inhibitor }\end{array}$ & Non-inhibitor & Inhibitor \\
\hline $\begin{array}{l}\text { CYP450 2C19 } \\
\text { Inhibitor }\end{array}$ & $\begin{array}{c}\text { Non- } \\
\text { inhibitor }\end{array}$ & Non-inhibitor & $\begin{array}{c}\text { Non- } \\
\text { inhibitor }\end{array}$ & Inhibitor & Inhibitor & $\begin{array}{c}\text { Non- } \\
\text { inhibitor }\end{array}$ & Inhibitor & $\begin{array}{c}\text { Non- } \\
\text { inhibitor }\end{array}$ & Non-inhibitor & Inhibitor \\
\hline $\begin{array}{l}\text { CYP450 3A4 } \\
\text { Inhibitor }\end{array}$ & $\begin{array}{c}\text { Non- } \\
\text { inhibitor }\end{array}$ & Non-inhibitor & $\begin{array}{c}\text { Non- } \\
\text { inhibitor }\end{array}$ & Inhibitor & Inhibitor & $\begin{array}{c}\text { Non- } \\
\text { inhibitor }\end{array}$ & Inhibitor & $\begin{array}{c}\text { Non- } \\
\text { inhibitor }\end{array}$ & Non-inhibitor & Inhibitor \\
\hline $\begin{array}{l}\text { CYP Inhibitory } \\
\text { Promiscuity }\end{array}$ & $\begin{array}{c}\text { Low CYP } \\
\text { Inhibitory } \\
\text { Promiscuity }\end{array}$ & $\begin{array}{c}\text { Low CYP } \\
\text { Inhibitory } \\
\text { Promiscuity }\end{array}$ & $\begin{array}{l}\text { Low CYP } \\
\text { Inhibitory } \\
\text { Promiscuity }\end{array}$ & $\begin{array}{c}\text { High CYP } \\
\text { Inhibitory } \\
\text { Promiscuity }\end{array}$ & $\begin{array}{l}\text { High CYP } \\
\text { Inhibitory } \\
\text { Promiscuity }\end{array}$ & $\begin{array}{l}\text { Low CYP } \\
\text { Inhibitory } \\
\text { Promiscuity }\end{array}$ & $\begin{array}{c}\text { High CYP } \\
\text { Inhibitory } \\
\text { Promiscuity }\end{array}$ & $\begin{array}{l}\text { Low CYP } \\
\text { Inhibitory } \\
\text { Promiscuity }\end{array}$ & $\begin{array}{c}\text { Low CYP } \\
\text { Inhibitory } \\
\text { Promiscuity }\end{array}$ & $\begin{array}{c}\text { High CYP } \\
\text { Inhibitory } \\
\text { Promiscuity }\end{array}$ \\
\hline \multicolumn{11}{|c|}{ Toxicity } \\
\hline AMES Toxicity & $\begin{array}{c}\text { Non-AMES } \\
\text { toxic }\end{array}$ & $\begin{array}{l}\text { Non-AMES } \\
\text { toxic }\end{array}$ & $\begin{array}{l}\text { AMES } \\
\text { toxic }\end{array}$ & $\begin{array}{l}\text { Non-AMES } \\
\text { toxic }\end{array}$ & $\begin{array}{l}\text { Non-AMES } \\
\text { toxic }\end{array}$ & $\begin{array}{l}\text { Non-AMES } \\
\text { toxic }\end{array}$ & $\begin{array}{l}\text { Non-AMES } \\
\text { toxic }\end{array}$ & $\begin{array}{l}\text { AMES } \\
\text { toxic }\end{array}$ & $\begin{array}{l}\text { Non-AMES } \\
\text { toxic }\end{array}$ & $\begin{array}{c}\text { Non-AMES } \\
\text { toxic }\end{array}$ \\
\hline Carcinogens & $\begin{array}{c}\text { Non- } \\
\text { carcinogens }\end{array}$ & Non-carcinogens & $\begin{array}{c}\text { Non- } \\
\text { carcinogens }\end{array}$ & $\begin{array}{c}\text { Non- } \\
\text { carcinogens }\end{array}$ & $\begin{array}{c}\text { Non- } \\
\text { carcinogens }\end{array}$ & $\begin{array}{c}\text { Non- } \\
\text { carcinogens }\end{array}$ & $\begin{array}{c}\text { Non- } \\
\text { carcinogens }\end{array}$ & $\begin{array}{c}\text { Non- } \\
\text { carcinogens }\end{array}$ & $\begin{array}{c}\text { Non- } \\
\text { carcinogens }\end{array}$ & $\begin{array}{c}\text { Non- } \\
\text { carcinogens }\end{array}$ \\
\hline
\end{tabular}



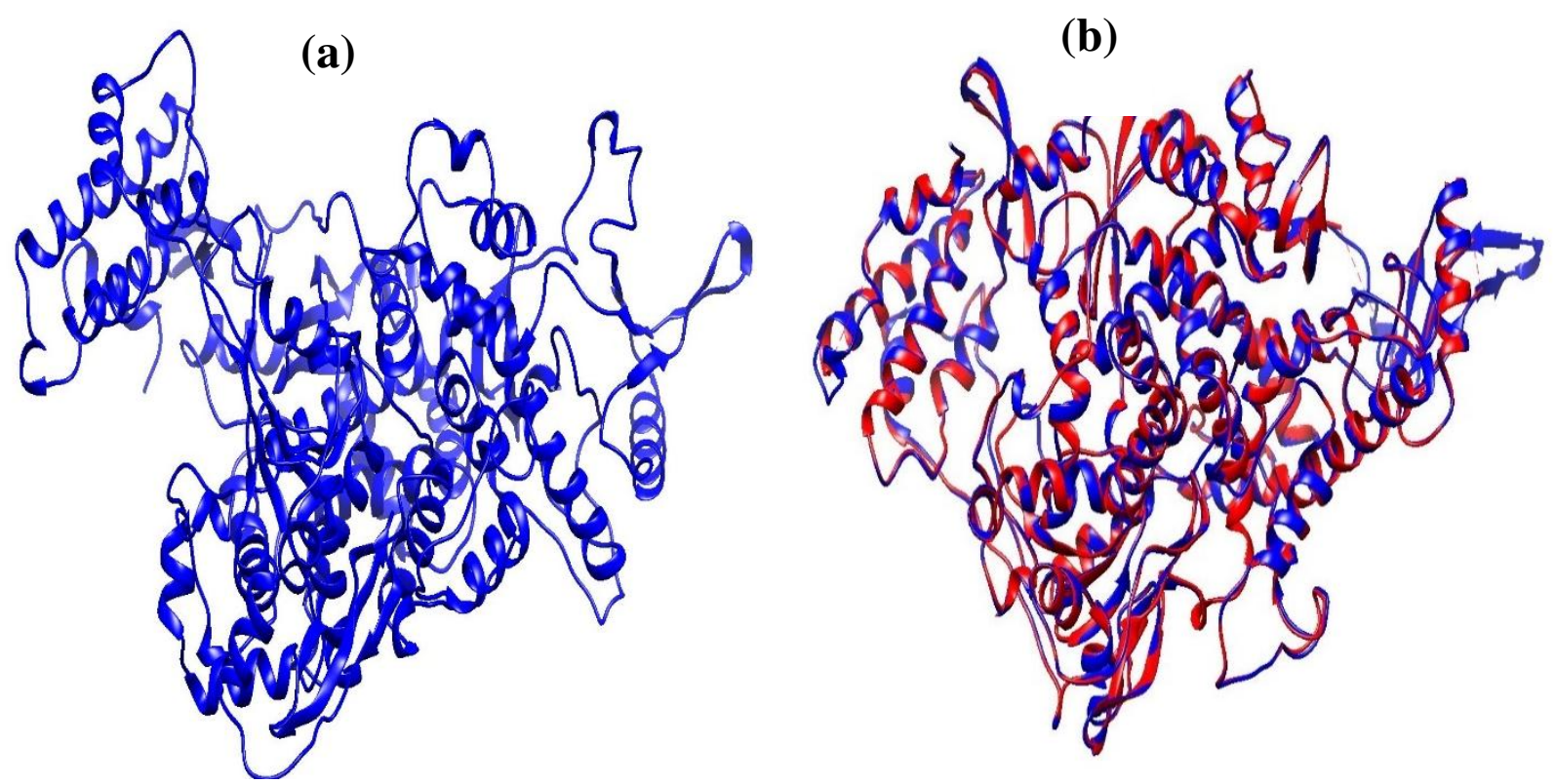

Fig. 1. 3D structure prediction of nsp-12 and its superimposition. (a) Predicted 3D structure of $\operatorname{RdRp}$ (nsp-12), (b) Superimposition of nsp-12 with selected template (the structure of nsp-12 is shown in blue and that of template in red) 

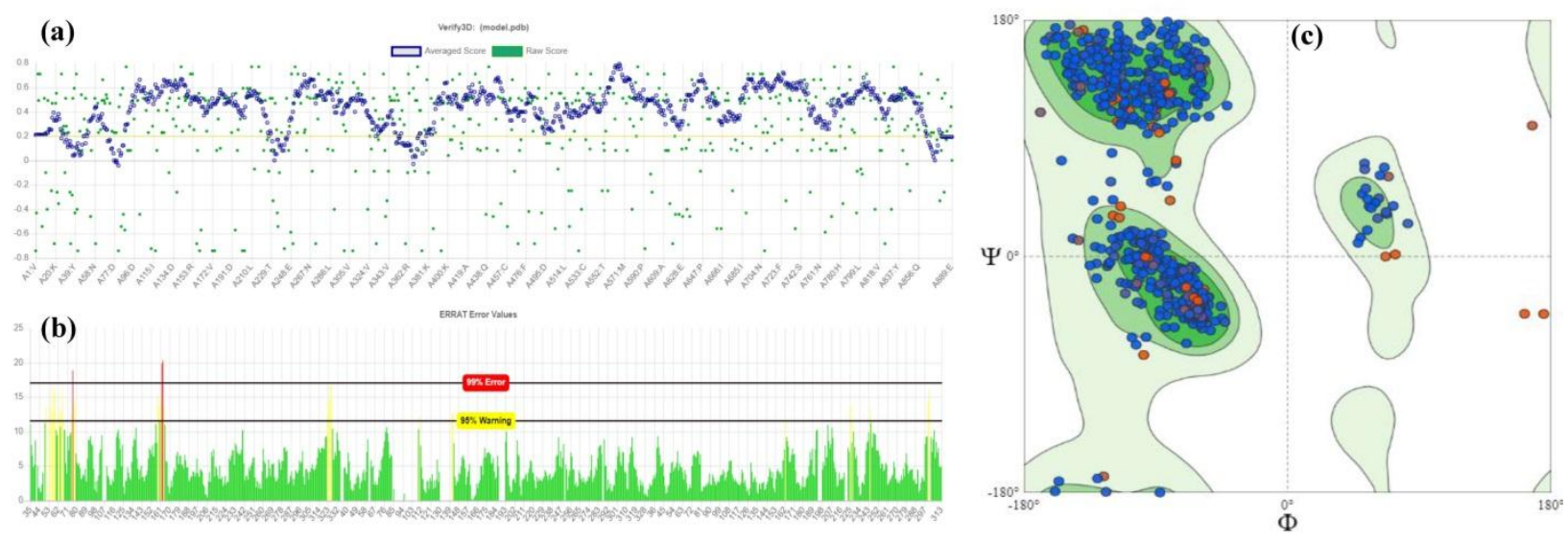

Fig. 2. Evaluation of predicted model of nsp-12. Evaluation via; (a) Verify 3D, (b) ERRAT, (c) Ramachandran Plot 


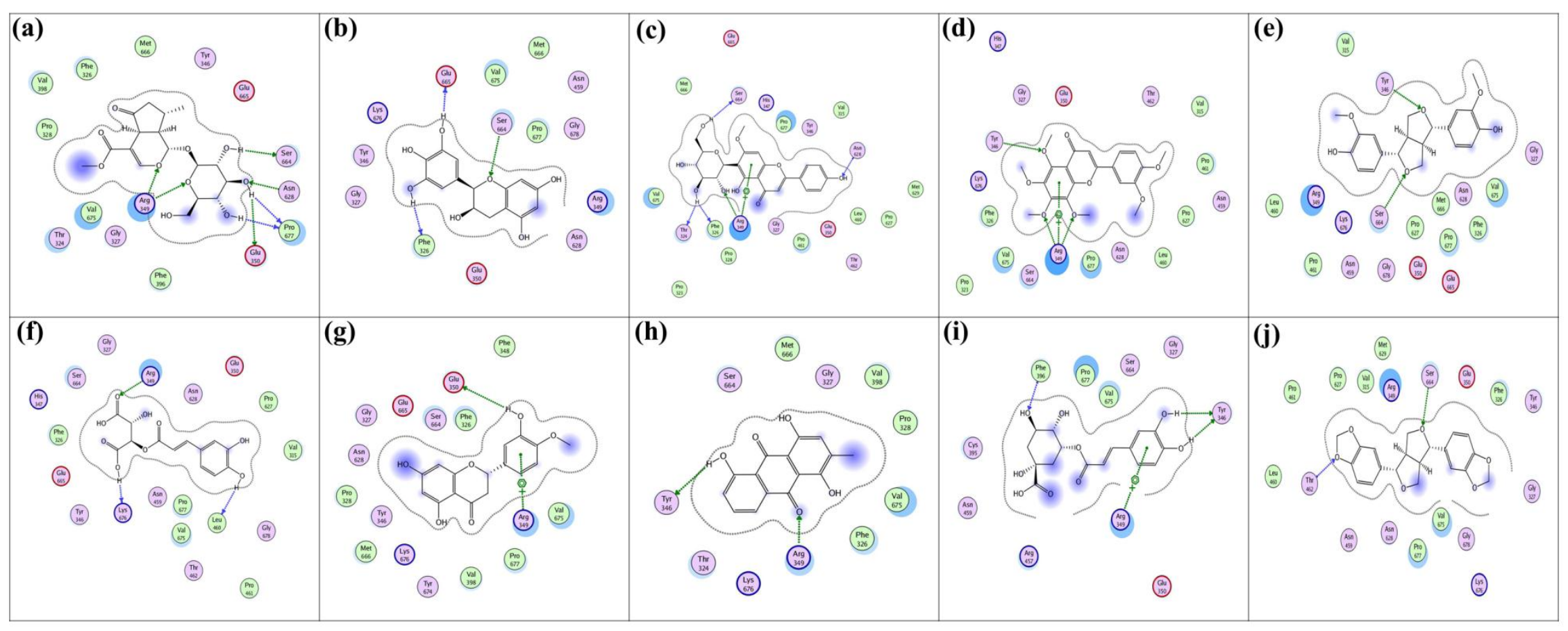

Fig. 3. Interactions of top ten ligands with nsp-2 of COVID-19 as target protein. (a) Verbenalin, (b) Epigallocatechin, (c) Swertisin, (d) Nobiletin, (e) Pinoresinol, (f) Caftaric acid, (g) Hesperetin, (h) Islandicin, (i) Neochlorogenic acid, (j) Sesamin 

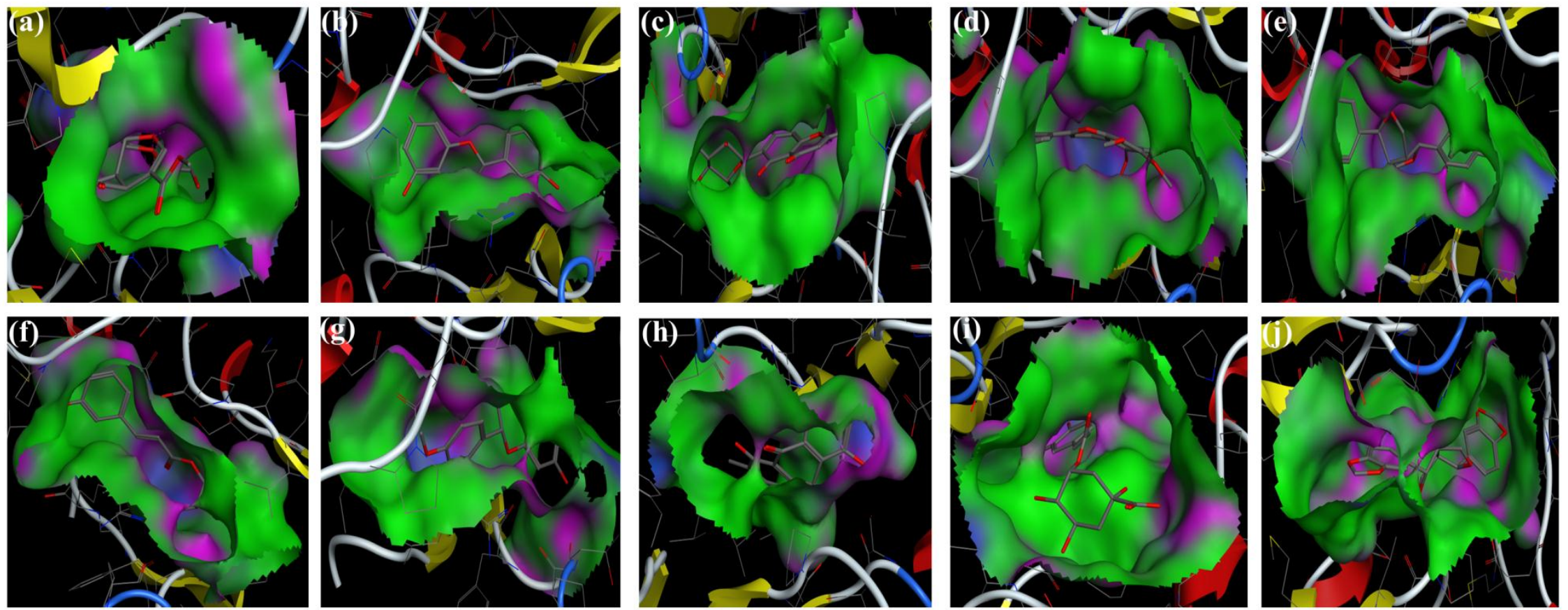

Fig. 4. Binding patterns of top ten ligands with nsp-2 of COVID-19 as target protein. (a) Verbenalin, (b) Epigallocatechin, (c) Swertisin, (d) Nobiletin, (e) Pinoresinol, (f) Caftaric acid, (g) Hesperetin, (h) Islandicin, (i) Neochlorogenic acid, (j) Sesamin 


\section{Figures}

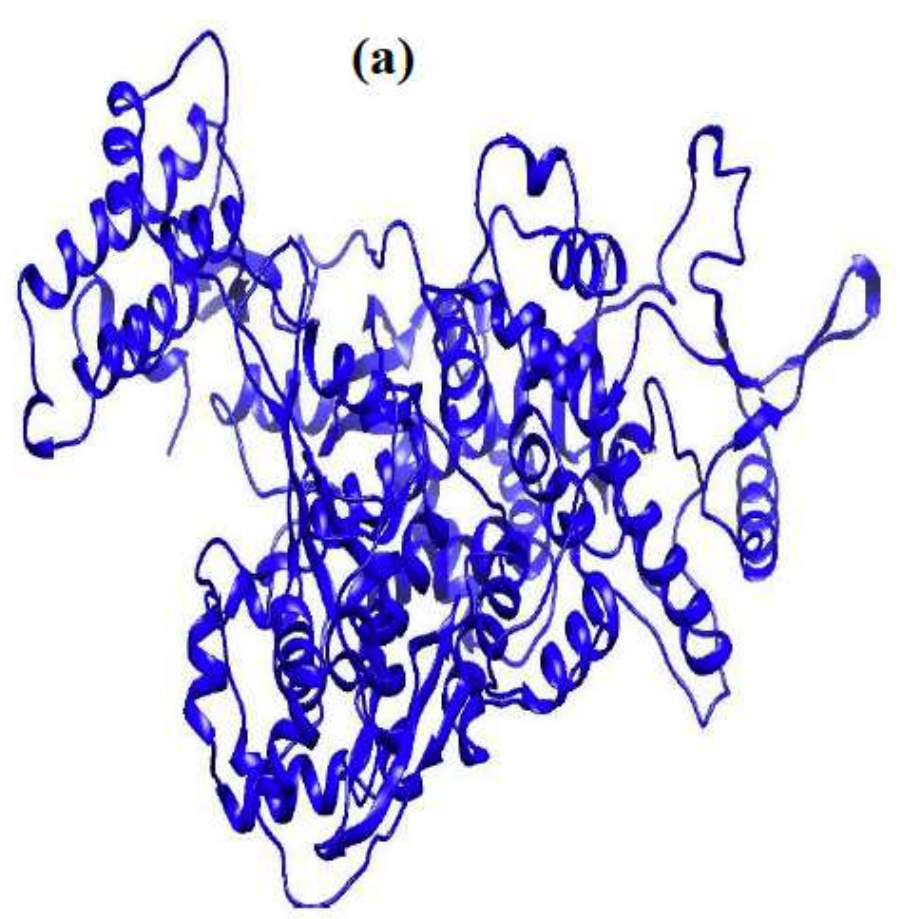

(b)

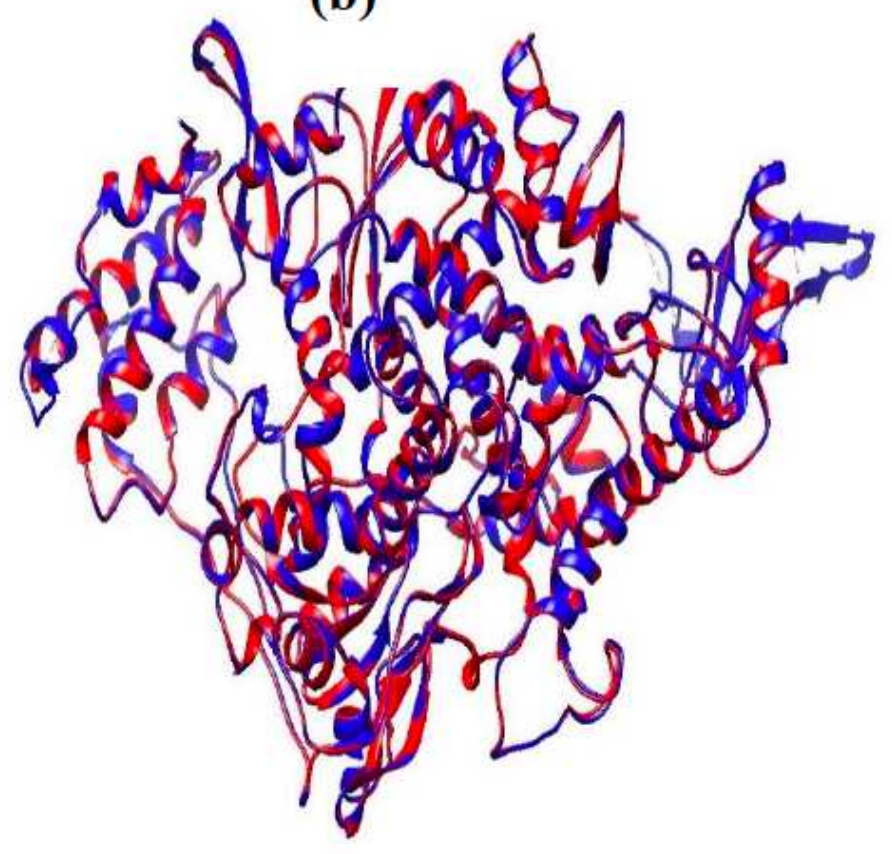

Figure 1

3D structure prediction of nsp-12 and its superimposition. (a) Predicted 3D structure of RdRp (nsp-12), (b) Superimposition of nsp-12 with selected template (the structure of nsp-12 is shown in blue and that of template in red)
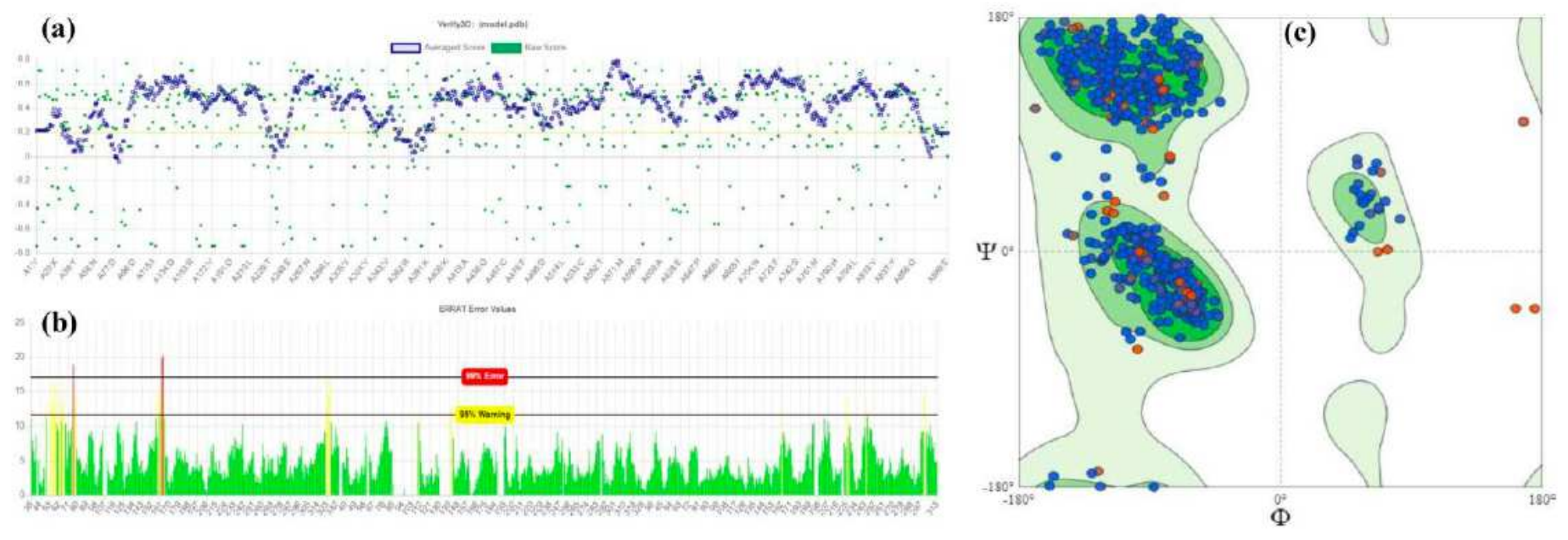

Figure 2 
Evaluation of predicted model of nsp-12. Evaluation via; (a) Verify 3D, (b) ERRAT, (c) Ramachandran Plot

\begin{tabular}{|c|c|c|c|c|}
\hline (a) (8) (8) (:) & (b) & (c) (i) & (d) (1) & 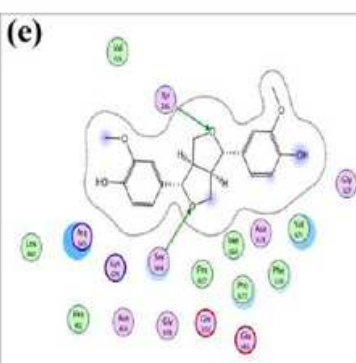 \\
\hline (f) (8) (8) & (g) & (h) (iii) (ii) & (i) (i) & (j) (4) (2) (2) (2) (2) (2) \\
\hline
\end{tabular}

\section{Figure 3}

Interactions of top ten ligands with nsp-2 of COVID-19 as target protein. (a) Verbenalin, (b) Epigallocatechin, (c) Swertisin, (d) Nobiletin, (e) Pinoresinol, (f) Caftaric acid, (g) Hesperetin, (h) Islandicin, (i) Neochlorogenic acid, (j) Sesamin
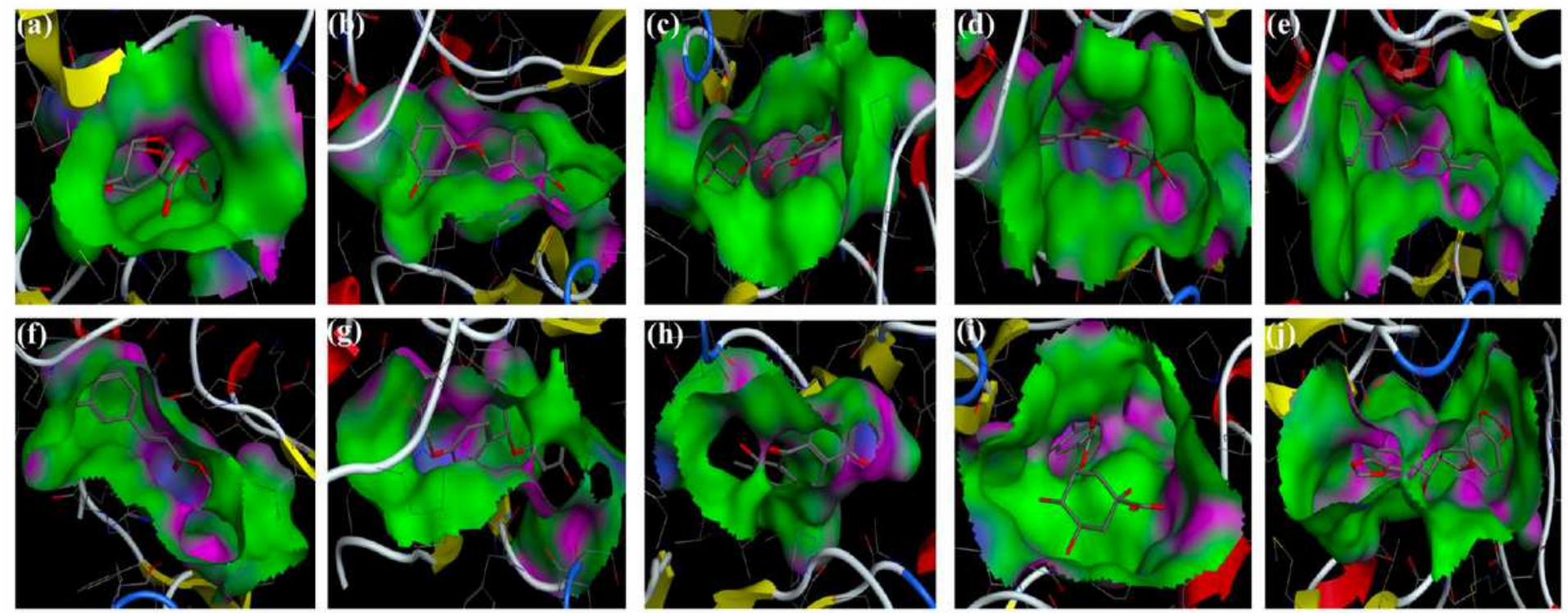

Figure 4

Binding patterns of top ten ligands with nsp-2 of COVID-19 as target protein. (a) Verbenalin, (b) Epigallocatechin, (c) Swertisin, (d) Nobiletin, (e) Pinoresinol, (f) Caftaric acid, (g) Hesperetin, (h) Islandicin, (i) Neochlorogenic acid, (j) Sesamin 